\title{
Giovanni Arduino - the man who invented the Quaternary
}

\author{
P.L.Gibbard
}

Scott Polar Research Institute, University of Cambridge, Lensfield Road, Cambridge CB2 1ER, England.

\begin{abstract}
A flowering of research into the natural environment and particularly geology took place in Italy in the eighteenth century. New concepts of the composition and formation of mountains and the structure of the Earth arose from regional field investigation of the lithology and palaeontology of the rocks, geomorphology and their relative position. Classification of mountains and the rocks from which they were formed developed rapidly following the critical insights into basic geological foundation principles by the Florentine scientist N. Steno. From this classification, a broad system of stratigraphical sequence gradually emerged in the form of a relative chronology based on the position and relative properties of the rocks. This led to the proposal of the terms "primary" (or "primitive"), "secondary," and "tertiary" to describe the nature of mountains and in addition the terms began to be used as stratigraphic units. By the middle of the eighteenth century, the mining engineer and field geologist Giovanni Arduino, following two decades of fieldwork in the Venetian and Tuscan mountains, made a remarkable contribution when he proposed a classification of mountain and rocks in northern Italy. His scheme divided the mountains and rocks into four basic units or "ordini" which were based on lithology, position and internal structure, yet excluded fossil evidence. The three orders of mountains and a fourth of the plains, were respectively: "Primary" (underlain by "Primitive or Primaeval" schist considered to be the earliest rocks), "Secondary" and "Tertiary". His youngest division, the "Fourth Order" or "quarto ordine" comprised alluvial and estuarine deposits that underlie river valleys or plains. His recognition of the "Fourth Order" was the first time that deposits representing the Quaternary had been identified and defined as a discrete sequence. In this way, Arduino's classification system of divisions laid the foundations of modern stratigraphy.
\end{abstract}

Keywords: geognosy, stratigraphy, mountains, eighteenth century, Italy, Orders.

\section{Introduction}

Much has been written and discussed concerning the history of Geology and its nomenclature. Most of us will be so familiar with the term Quaternary, as well as its closely related terms Pleistocene and Holocene, etc. but many might be unaware of who invented these terms and why, how and where they were originally applied to depositional sequences.

It is common knowledge, particularly to those who are familiar with the publications of Sir Charles Lyell, that he was responsible for inventing the terms Eocene, Oligocene and 
Miocene and Pliocene, as well as Pleistocene latterly, but the evolution of the terminology is less clear and in particular the origin of the apparent parallel terminology represented by Quaternary versus Pleistocene etc.. The classification and interpretation of the youngest stratigraphic sequences, variously known as Pleistocene, Holocene or Quaternary, have been a matter of much debate even in recent years. The term Quaternary has been particularly challenged since it has been regarded as the remnant of what some consider an apparently outdated Latin-based terminological scheme. But what is the origin of this scheme and why is it potentially anachronistic? To answer these questions we have to look back at the history of the terms which began in the seventeenth to eighteenth centuries.

When considering these questions it is important to realise that in the early development of study of the Earth's rocks there was no such science as geology until the end of the eighteenth century (Adams, 1932; Eyles, 1969), although the term had been used in the modern sense earlier in the century by Deluc and Saussure (Gohau, 1991). Before then scholars of the earth's geology were called geognosts. They were principally groups of amateurs and professional mining engineers, mineralogists and metallurgists who through their investigations collected rocks and fossils which they came across.

Exploitation of metallurgical and mineral resources, as well as building stone excavations, were the main means by which inquiringly minded naturalists were motivated to examine the rocks that lay beneath their countries' landscapes.

The following article explores the role of one such early geognost, Giovanni Arduino, whose influence on the concepts of geological evolution and thinking on stratigraphical geology in eighteenth century Italy cannot be over-estimated. This Veronese geologist, who, together with his contemporaries, established a fundamental field-based approach to geological investigation almost a century before Charles Lyell published his 'Principles of Geology' (1830-3). This article is an historic review that relies substantially on the detailed biographical study of the life and work of Giovanni Arduino by Vaccari (1992, 1993, 1996, 2006) and other sources stated in the text.

\section{Giovanni Arduino, his life and contemporaries}


Giovanni Arduino (Fig. 1) was born into a modest family in Caprino Veronese in northern Italy on 16 October 1714 and died in Venice on 21 March, 1795. Among his many lifetime achievements he was Professor of chemistry, metallurgy and mineralogy in Venice and in many ways is regarded as the founder of stratigraphical mapping in Italy, as well as being a general geologist.

His initial training in what we now call Earth Science was at Verona, where he was supported by a patron (Gliozzi 1962). However, at eighteen he abandoned his theoretical studies to begin an apprenticeship as a technician in the iron-ore mines in Klausen (Cliusa), in Bozen (Bolzano), northern Italy. Here he quickly learnt about mineralogy, metallurgy and as he himself described he was eager to discover "everything about the science of the fossil kingdom" (Arduino 1770; Gliozzi 1962), moving latterly to Bergamo and Moderna in 1740. He completed his training in Tuscany and the Modenese Apennines after gaining eight years' experience in mining in Vicenza. Although he was principally interested in rock lithologies and their mineral contents, his interest in palaeontology was sparked by the remarkable finds at Bolca, near Verona. Here a spectacular Eocene-age fauna, particularly yielding remarkable fish fossils and other marine vertebrate and invertebrate organisms was found. But in his professional life, Arduino continued to be concerned with lithology and mineralogy.

On his return to Vicenza, he was first appointed as an expert and later as engineer of the Municipal Property Magistrate (Gliozzi 1962). By the early 1750s Arduino was still an unknown Veronese mining expert when he visited the Montieri hills near Siena to examine the area for potential mining by a company from Livorno (Vaccari, 1996). Latterly Arduino was appointed to the position of land surveyor at Vicenza before being nominated agricultural superintendent of the Republic of Venice in 1769, where he worked for the rest of his life (Vaccari, 1992; 2006).

According to Gliozzi (1962), his employment in public office in Venice led Arduino to focus on the study of various practical mining, metallurgical and agricultural problems. He was clearly both practical as well as multi-talented, for example in 1754 he developed a more practical surveying compass than others then in use; he also invented a new type of reverberation furnace, successfully experimented in Agordo and then in the saltworks of 
Bema, for which he obtained a gold medal from the Venetian Senate in 1791, among other non-geological achievements.

However, for Arduino, his mining experience gave him a remarkable amount of practical and technical knowledge, which according to Vaccari (2006), included a specialized terminology of borrowed terms from German, no doubt influenced by his having worked in the Tyrol region. However, his real skill and his "dominant passion", as he says, (Arduino 1770; Gliozzi 1962), was undoubtedly his ability to observe and study the structure of the hills and mountains in order to obtain a precise idea of their possible mineral resources. From his experience in the mines of Vincenza, Tuscany and Moderna, Arduino began to assemble the skills that enabled him to evaluate the rocks he encountered. There can no doubt that his technical apprenticeship and mining exploration formed the foundation of his geological investigations in the 1750-60s, and above all of the lithological "classification" of the four units (ordini), he outlined for the first time in two letters sent to the Paduan naturalist Antonio Vallisneri the younger (1708-1777) in 1759, subsequently published in Venice (Arduino, 1760).

In the first half of the eighteenth century studies of the Earth were yet to be regarded as a true science in the modern sense. Whilst many were interested in collecting fossils and minerals, there was no coherent subject of study, rather this collecting reflected a general interest in natural history and associated objects. Few attempted to interpret their significance in any meaningful way. The exception was the famous father of stratigraphy, the Dane Niels Steensen, better known by his Latinised name Nicolas Steno (11 January 1638 - 5 December 1686). Steno was an anatomist and latterly a Catholic bishop in Florence (Firenze), where after walking in the hills above the city he examined fossils preserved in local rocks. From 1659 he began questioning the established ideas of the natural world. In particular he questioned the current opinion that fossils were formed in the rocks and therefore he questioned the genesis of rocks in which the fossils occurred, as well as their layered or stratified character. He interpreted the rocks as being sediments originally laid down in a fluid (water) and the fossils contained within them as being the remains of once living organisms. He also noted the way in which erosion of stratified rocks could explain the formation of mountains and valleys, the latter being filled by new strata formed from the destruction of the former. His observations on these topics mean that today he is genuinely 
regarded as one of the founders of modern geology and particularly stratigraphy (Mather \& Mason, 1970).

In 1667-1669 Steno published his observations and conclusions in his Dissertationis prodromus (1669) in which he presented his four defining principles that form the basis of stratigraphy to this day: the law of superposition, the principle of original horizontality, the principle of lateral continuity and the principle of cross-cutting relationships. These concepts were later developed in the British Isles by James Hutton (3 June 1726 - 26 March 1797) to support and elaborate his concept of 'infinitely repeating cycles' in Earth's history, a view fundamental to geognost philosophy throughout the eighteenth century.

Although Arduino was largely self-taught, there were several individuals whose thinking influenced him. One such person was Antonio Vallisneri (3 May 1661 -18 January 1730), an Italian medical scientist, physician and naturalist who held the chairs of Practical and later Theoretical Medicine at the University of Padua in 1700-1730 (Luzzini 2008; 2011). Apart from his medical studies, he was also very interested in the natural sciences, being a collector of numerous specimens of animals, minerals and other natural objects. He believed that these remains supported the idea that the Biblical Flood was responsible for their deposition. Unfortunately his explanation for the discoveries of fossils in mountain top rocks was strongly influenced by religious belief; the only possibility he allowed for being the Noachian Biblical Flood as the cause for their deposition .

It is important to understand that these early geognosts, like Vallisneri, not only developed their classifications on the basis of the rocks, but also they considered the morphology of the mountains that the rocks formed. Therefore in a sense, the classification was essentially a combination of geology (principally lithology) and geomorphology (Rudwick 2005). So the divisions are those of the mountains and not solely the rocks themselves.

According to Vaccari (2006) in his book, De’ Corpi Marini, Vallisneri (1721) strongly supported Steno's field-based investigation method, travelling and undertaking fieldwork throughout the northern Apennines (Fig. 2). He apparently accepted the concept of primitive and permanent mountains created by God (eroded or modified by floods and earthquakes). He thought that these "primitive" mountains had remained unchanged since the Biblical Creation. For Vallisneri (1721) these mountains and their rocks were the foundation of the 
Earth (Vaccari 2006) and for this reason he rejected the mountain building action of an unique universal flood like that proposed by earlier geognostic philosophers. Vallisneri's emphasis on the importance of the study of what he called the anatomy of mountains (la notomia de' monti: Vallisneri, 1715, p. 66) undoubtedly influenced Arduino's thinking.

Arduino was not therefore the first to consider how to classify mountains. According to Vaccari (2006) by the mid-eighteenth century, two major figures in Italy proposed different ways in which mountains could be classified. Anton Lazzaro Moro (1687-1764) and Giovanni Targioni Tozzetti (1712-1783) proposed a two-fold division scheme. Like Vallisneri, Moro (1740) strongly attacked earlier ideas by Burnet (1681) and Woodward (1695) who attributed marine accumulations to the Universal Deluge (Mather \& Mason, 1970). Instead he developed an original "classification" of mountains into "primary" and "secondary" divisions. The "primary" mountains (monti primari), uplifted from the bottom of an ancient sea by subsurface (plutonic) heat, like submarine volcanoes, were composed of massive, generally crystalline rock, and they were unstratified. These mountains were considered to form the highest parts of the Alps; their shape being usually illustrated and described as jagged. By contrast, his "secondary" mountains (monti secondari) consisted of stratified rocks deposited at the surface at differing times; the materials originating from volcanic eruptions derived from the former "primary" mountains. These secondary rocks frequently included fossils and debris that had accumulated on the floor of an ancient sea (Moro, 1740). As Rudwick (2005, p.91-92) notes, this division into "primary" and "secondary" rocks, which German geognosts called the "fundamental rock masses" and "layered rock masses" respectively, is essentially similar to the modern informal divisions of 'hard' (crystalline basement) versus 'soft' (sedimentary, often fossiliferous) rocks, used by modern geologists.

It has been generally thought that Moro was the first to apply the terms "primary" and "secondary" to the classification of mountains (Adams, 1938, p. 368). However, according to Vaccari (2006), this two-fold terminology had already been used by Burnet (1681, p. 94 95) who suggested that the montes primarii ("primary" mountains) appeared on the surface of Earth, having neither been created by God nor resulted from the Noachian deluge, and a group formed of the fragmented materials derived from the 'primary' rocks which he called monticulos secundarios (Vaccari 2006). Moro's interpretation of destruction by volcanicgenerated uplift was apparently based on reports of the appearance of the Nea Kameni 
volcanic island beside Santorini in the Aegean Sea in 1707 (Moro, 1740; Vaccari 2006). Despite, Moro's conclusions being strongly criticised by the Italian supporters of diluvianism, his field-based approach of examining mountain topography and attempting to classify it in a simple chronological fashion was welcomed by Targioni Tozzetti (Arrigoni, 1987), the Florentine natural scientist who was a strong advocate of Steno's primary stratigraphical concepts.

Based on his observations in Tuscany, combining historical, economical and scientific information, between 1751 and 1754, Targioni Tozzetti published Relazioni (six volumes of reports) on his detailed regional geological research (Targioni Tozzetti, 1751-1754). Through these studies, as well as in an unpublished study on the "physical topography" of Tuscany (Targioni Tozzetti, 1754, p. 11-42), he proposed classifying the Tuscan mountains into two units which he termed the monti primari (i.e. "primary") or monti primitivi (i.e. "primitive"). According to Vaccari (2006), Tozzetti's “primitive" mountains were formed by the oldest rocks comprising irregular, contorted and composed of schistose rocks with mineral veins (which he termed filoni $=$ strands); whereas the hills of more recent formation, whereas the younger hills (or colline $=$ hills) were composed of flat-lying, bedded fossil-bearing sandstones, clays and volcanic tuffs. He understood, however, that his scheme could only be related to the present surface of the Earth, and that perhaps what he had identified as "primary" mountains may ultimately be found to be younger when compared to other regions, i.e. "secondary" or "tertiary" (Table 1). He concluded this since he realized that the materials from which these stratified "primary" rocks were formed were derived from the debris of the earlier ancient (i.e. "primitive") mountains. This evidence allowed Targioni Tozzetti to identify only fragments of what he surmised was a longer history of the Earth's surface. It is important to realise that this classification was based almost exclusively on lithological and geomorphological evidence, since there was no independent means of dating the mountains and the rocks from which they were formed. This was because the application of fossil assemblages to provide or support his chronology was limited to noting their presence rather than their detailed identification.

As a consequence of his field experience, and especially his observation of volcanic activity, Targioni Tozzetti (1779) refused to accept Moro's volcanic uplift concept, instead preferring to emphasise the role of marine erosion and denudation arising from ground water and particularly streams, the latter being responsible for forming valleys (Mather \& Mason, 
1970). Through his long and careful field observation he realised that only fragments of the geological evolution of the Earth's surface could be reconstructed from the preserved evidence (Vaccari, 1996; 2000, p. 173-175; 2006).

\section{Arduino's four orders}

Following his field excursions in the valleys north of Vicenza in 1758-9, extending north from the Po valley into the Apuane Alps, Arduino (1790) proposed his general stratigraphical division concept (Arduino, 1760). This scheme was based principally on the lithological properties characterising the division of the mountain rocks into four orders (ordini), which comprised mountains defined as "primary" (primari), "secondary" (secondari), and "tertiary" (terziari), as well as the terrain of the alluvial plains, which was considered as belonging to a "fourth" (quarto) unit. Each order was thought to be separated by 'a major revolution of Earth systems. Despite his more accurate description of lithological terms he encountered than those presented by Moro and Targioni Tozzetti, Arduino's classification was based on experience accumulated from two decades of observations in northern Italy, part of the Modenese Apennines, and the metalliferous hills of Tuscany. In principle his detailed classification represented a systematic lithological analysis in which he attempted to describe the characteristic rocks of each individual division. Apart from his four orders, Arduino also recognized what he termed "primaeval" rocks (roccia primigenia). These occurred at the base of all the landscape he investigated and therefore he assigned these to having formed before his other orders. Arduino had already identified this basal unit of crystalline schists in his lithostratigraphic classification in the Apuane Alps. Moreover, he added a newer sequence to his "tertiary order" (terzo ordine) "the hills of tuff and clay of Tuscany" (le colline di tuffo e d'argilla della Toscana) which had previously been described by Targioni Tozzetti and who by implication saw them as "secondary". By re-assigning these rocks as "tertiary" Arduino (1760) distinguished them from their previous, less confident classification by his predecessor.

It is important to emphasise that Arduino's lithostratigraphical classification was much more sophisticated and at the same time, a more accurate description than the proposals by his contemporaries, both within his native Italy and elsewhere in Europe. Vaccari (2006) states that Arduino considered his 'four-order divisions' as four large strata (quattro grandissimi strati) superimposed, which were themselves internally layered being composed of many 
minor strata (strati minori). Importantly, he concluded that these strata were deposited successively at different times and under different conditions. In his Second Letter, Arduino's states: "From what I have been able to observe, the series of these strata, which make up the visible crust of the Earth, seem to me to be distinguished in four general orders, and to be successive, without considering the sea. These four orders may be imagined as four large strata, which in all places where they are exposed, may be seen positioned one above the other, in a constantly uniform way. Although each of these large strata are a union of numerous other minor strata, composed of many types, species and varieties of material, nevertheless considering all the components as a whole of each of the said orders, and principal strata, and comparing one order with another, one can see the diversity of nature, and of events which clearly make known that they were formed, not only in different times but also in quite diverse circumstances" (Vaccari 2006, p.20).

In subsequent publications and especially in his Saggio Fisico-Mineralogico di Lythogonia e Orognosia (Physical-Mineralogical Essay of Lithogony and Orognosy: Arduino, 1774, p. 243, 260-281) (Fig. 3), he assigned the name schisto (schist) to the "primaeval" rock, today interpreted as metamorphic crystalline quartz and mica rock. He also identified this schist in the base of the Alps and Venetian Prealps.

In Arduino's lithological classification scheme (Table 1), his "first order" rocks were the "primary mountains" (monti primitivi o primari). These strata overlaid his "primaeval" rocks and were formed of sandstones and conglomerates ("a mixture of pebbles, sand, and dust of the primaeval rocks", and also included igneous granitic intrusive rocks. The absence of fossils from these mountains allowed Arduino to differentiate the first-order layered rocks from those of the second, i.e. those forming the "secondary mountains" (Arduino, 1760, Vaccari 2006). These "second order" rocks comprised strata of limestones and marble, including fossils, but lacking mineralisation (translation by Vaccari 2006). Today therefore we would interpret these rocks as fossiliferous limestone laid down under the Tethyan marine conditions during the Mesozoic Era, or as Ellenberger (1994, p. 262) states, they are the "true daughters of an antique ocean". In this sense Arduino presents the first stratigraphy of the Mesozoic rocks.

The "third order" mountains were more subdued, being composed of the remnants of "shells, fragments, and sands of testaceous marine animals: and fragments, pebbles, sands and 
fragments originated from the destruction of large portions of the primary and secondary mountains" the material underlying the "tertiary" mountains and hills (Arduino, 1760; Ellenberger 1994, p. 263). According to Vaccari (2006), these materials comprise limestones, sandstones, clays and conglomerates yielding the remains of more modern animals. Rudwick (2005) notes that these superficial and alluvial deposits were not 'rock masses' but unconsolidated gravels, sands, silts and muds usually found in river valleys and estuaries and low-lying plains. They were thought very recent relative to Secondary rocks, since they contained clasts of the Primary and Secondary rocks; the great German Neptunist geognost Abraham Gottlob Werner (25 September 1749 - 30 June 1817) later referring to them as 'washed-out deposits'(Rudwick 2005).

In addition to these stratified, predominantly marine rocks, Arduino (1760) also identified what are now known as the Oligocene volcanic rocks that occur in the Venetian Prealps, stating that "the entire hills of those vitrifiable clumps and tuffs, all perforated and spongelike of various colours, which seem like pumice and lava of ancient volcanoes" (translation by Vaccari 2006). He also included these igneous eruptive products, together with associated non-volcanic lithologies in his "third order". According to Vaccari (2006), here Arduino (1760) disagreed with Targioni Tozzetti, who had excluded these volcanic products from his "classification" scheme.

Of particular significance to today's Quaternary community, Arduino's (1760, p. 169) "Fourth Order" is most relevant. This "Fourth Order" did not include the mountain-forming rocks but instead included "all the plains, which are also formed by layer upon layer, by floods, and deposition of material brought down from the mountains by the waters of the rivers can be finally identified in the alluvial deposits" (modified from Vaccari 2006) and in the unroofing arising from erosion during the 'Neozoic' or Quaternary Period.

Before Arduino the original concept of the fourth order among geognosts was of the volcanic rock masses, based on their relative position and the nature of the rocks, not particularly on their relative age (Rudwick 2005, p.93). Conversely, Arduino included these rocks in his 'Third Order' (or "monti terziari") as stated above, instead assigning to his "Fourth Order" materials that were essentially different from those that formed the mountains of the other three orders. This was because the deposits floored the valleys forming plains, and in some instances occurring in more elevated positions, but separated from the previous orders by a 
substantial intervening period of erosion. This essential difference might explain why, although Arduino recognised that they constituted a discrete depositional system (in modern parlance), the alluvial materials of the plains were clearly relatively much more recent in origin ( $c f$. Rudwick 2005, p.93). It is also possible that he recognised that these deposits were of limited interest to him since they were not important to the extraction industry. Whatever the reason, the "fourth order," remains the least treated of the four lithostratigraphical-chronostratigraphical units of Arduino's classification system.

Technically speaking, the title of the present article is incorrect, however, since Arduino never proposed the term 'quaternario' sensu stricto. Nevertheless it is patently clear that in defining his 'quarto ordine' he was implying that this fourth division could be identified, characterised and differentiated in the same fashion as his three other orders. Whether he intended this as indicating a strictly chronological sequence is another matter. However, there can be no doubt that his four orders correspond remarkably closely to the four eras that are still in use today (Ellenberger 1994, p. 263) (see below).

Arduino's Due Lettere recorded his observations and conclusions arising from his extensive fieldwork in different areas, and his critical conclusions on the classification of rocks and mountains undoubtedly arose following his excursion in October 1758 to the Agno Valley in the Alpine foothills north of Vincenza (Fig. 4). This $20 \mathrm{~km}$ transect along the valley apparently convinced Arduino that he could see a consistent general pattern in his geological and geomorphological observations in the Alpine and Apennine regions (Vaccari 1994; 2006). The most outstanding item among his geological manuscripts and field notes, preserved in the Biblioteca comunale in Verona, is his unpublished geological sketch section along the Agno Valley from Montécchio Maggiore to the Recoaro basin (Fig. 4) of "exploration of deep caves, especially those of the Berici mountains, with particular attention to the formation of stalactites" (Grossi 2015). The Agno valley drawing which dates from 1758 provides a beautiful illustration of Arduino's lithostratigraphical classification scheme, although the labelling does not identify the "four orders" which he later proposed. This figure records the rocks exposed along the valley sides, the lithologies, and their associated topographic expression and colour providing the basis for his differentiation into 15 units labelled from A to $\mathrm{R}$ - his fourth order being shown on the extreme right at Montécchio Maggiore. A present-day view of the Agno valley (Val d'Agno) for comparison with Arduino's sketch is shown in Fig. 5 . 
Vaccari (2006) notes that it is curious that in his Due Lettere Arduino (1760), in common with earlier workers such as Targioni Tozzetti, did not include discussion of the fossil assemblages that characterised his chronological reconstruction of the history of the Earth. He merely noted the presence of the "remains of marine inhabitants" which he mentioned only as a guide to the differentiation of the "Primary" and "Secondary" rocks, apparently failing to remark on the differences between the palaeontology of the "second" or "third order" strata.

In a letter dated 18 January, 1758 to Antonio Vallisneri's son, Arduino speaks of ".. the great difficulty that has, especially in our Italy, to make collections of rocks, minerals and fossils, not only of the regions distant to us, but also the countries that are close to us ..." and in another, the 3 April, 1758 to Jerome Festari, shows his passion for a discipline that also allowed him to study regions far from his Venetian home: "He continues with courage, perseverance and began the journey, and face this honour in itself, the motherland [Venice] and Italy" (Grossi 2015). In common with many of his fellow Italian geologists, Arduino realised that the similarities between the geology of the Italian peninsula, areas belonging to different states at that time, lent support to the movements for Italian national unification that was to become a reality in 1871 .

Among his manuscripts, which have partly been published, are sketches, geological sections and mining plans. These documents also indicate that Arduino was a forerunner in modern geological mapping. The correspondence and Arduino's mostly unpublished manuscripts are kept by the Biblioteca comunale in Verona; other manuscripts, related to his researches and studies of the Tuscan mines, are kept in the Biblioteca nazionale in Florence (Palatina section); a bas-relief medallion is mounted in the inner courtyard of the Palazzo Ducale in Venice and a bust is installed in the vestibule of the municipal building of the Caprillo commune (Gliozzi 1962).

\section{The term Quaternary - developments after Arduino}

As already mentioned Arduino never actually used the term 'Quaternario'. The first person to do so was the French geologist Jules Desnoyers in 1829 who studied the Tertiary rocks in the Paris Basin, the Loire, Gironde, Hérault and Rhône basins, and in Italy elsewhere. In fact 
he only used the term Quaternaire (or Tertiaire récent) twice, and then in a rather disparaging manner, even waiving it in the same publication because of the transitional nature of this interval with underlying the "older Tertiary" rocks (Desnoyers, 1829, footnote on p. 193). He applied the term Quaternaire to the unconsolidated deposits gravels, sands and fine sediments that unconformably overlie the Tertiary rocks of the Paris Basin (Bourdier, 1957). So it fell to his countryman to clarify the term's definition. De Serres (1831) considered the Quaternaire synonymous with the Diluvium (material supposedly laid down during the Biblical Flood or Universal Deluge) and noted that humans were contemporaneous with these deposits. But it was not until 1833 that the term was finally defined palaeontologically by H. Reboul who remarked "This is why one had to call Quaternary, the subsequent period, which is characterised by plant and animal species similar to those that occur in the same places today" (Reboul, 1833, p. 1,2). Reboul credits Desnoyers as being first to use the term Quaternaire, which he used unequivocally to distinguish the deposits from those of the Tertiary.

Among others, to adopt Arduino's four divisions was the great French anatomist and palaeontologist Jean Léopold Nicolas Frédéric, Baron (Georges) Cuvier (23 August 1769 13 May 1832), generally considered as the 'founding father of palaeontology', who pointed out the characteristic faunas associated with each division. He noted that the Quaternary fauna was typically that of the present-day, and included apes and man. He concluded that some of the faunal elements, such as mammoth, mastodon, woolly rhinoceros and giant deer had fallen victims to the last great geological catastrophe, the Biblical Flood, whilst other taxa had survived to the present day (Wendt 1968, p. 97-98).

Subsequently the terminological evolution continued. Of particular importance was Lyell who independently proposed the term Pleistocene in 1839 for the post-Pliocene period closest to the present (Boylan 1998). As is well known, he defined this period on the basis of its molluscan faunal content, the majority of which are still extant, although later he retracted the term (Lyell 1863). However, both terms Pleistocene and Quaternary became latterly synonymous with the Ice Age and also with the period during which humans evolved, once it was realised that the period was characterised by major glaciation. This theme has characterised the definitions of both Pleistocene and Quaternary up to the present day. However, unlike the Pleistocene concept, the span of the Quaternary included Lyell's original "Recent", later named Holocene at the 3rd International Geological Congress (IGC) in 
London in 1885. The term Holocene (meaning "wholly recent") refers to the percentage of living organisms and was defined by Gervais (1867-1869) "for the post-diluvial deposits approximately corresponding to the post-glacial period" (Bourdier, 1957, p. 101; Gibbard \& van Kolfschoten 2004; cf. Walker et al. 2018). So, by the late nineteenth century the terminology of the Quaternary Period was firmly established (Elias 2007).

Although Arduino's four-order terminology has effectively been replaced in modern geology by the familiar Greek-language terms, the Primary or Primaeval rocks being effectively Precambrian, and latterly Palaeozoic (proposed by Sedgwick 1838), the Secondary rocks being essentially Mesozoic, and the Third order rocks being of Caenozoic age (Phillips 1840; Rudwick 2005), the Latin-based terms Primary and Secondary are still in occasional use to this day. Moreover, despite concerted attempts in some quarters to suppress them, even in the last few decades, the terms Quaternary, and to a lesser extent Tertiary, have refused to be replaced, remaining in current usage in many situations (Head, Gibbard \& Salvador 2009; Knox et al. 2012; Gibbard et al. 2009).

\section{Conclusion}

Seen from today's perspective it is striking how Arduino's detailed field observation and systematic description of the rocks and landscape of his native Italy allowed him to reach such astonishingly influential actualistic conclusions regarding Earth history. Clearly the vibrant philosophical environment of Italy during the eighteenth century, together with remarkable diversity of the region's geology, provided a fertile setting for the Veronese geognost to develop his remarkably insightful concepts. His experience and keen observations enabled him to establish his geological approach and propose his classification based on mapping in the year of William 'strata' Smith's birth. Moreover, there is no question that Arduino's classification scheme, although it was based solely on the sequences of rock strata, mountain morphology and the deposits formed by them at the Earth's surface, is still considered valid by most present-day historians of geology. For example, the geologist Michele Gortani (1930) comments that Giovanni Arduino was nothing less than the "instigator of stratigraphic geology and of its great chronological divisions", whilst Ellenberger (1994, p. 264) agrees that Arduino is "one of the greatest pioneers of his science and the most modern of the eighteenth century geognosts". For those of us who study recent Earth history, the definition of his "fourth order" was undoubtedly the first instance of 
recognition of a discrete and distinctly separate interval which was to become the Quaternary Period in modern geological classification. Although challenges to its usage have been regularly introduced, the continued use of this term is assured since it remains of central importance in the division of Earth history to this day.

Ellenberger (1994, p. 265) concludes that Arduino "gives us a marvelous lesson in field geology, rigorous, precise, vast, but free from vain speculations, that has not aged".

"So great and wonderful are the works of nature." (G.Arduino) (from Grossi 2015).

Acknowledgements

I thank Dr Bryan Lintott and Professor Thijs van Kolfschoten for encouraging me to publish this article, and Professors John Lewin and John Mather for their helpful comments.

References

Adams, F.D., 1938. The birth and development of the geological sciences. London, Baltimore. Williams \& Wilkins, 506 pp.

Adams, F.D. 1932. Earliest use of the term Geology. Bulletin of the Geological Society of America 43, 121.

Arduino, G. 1770. Giovanni Arduino ai Provveditori Deputati sopra l'Agricoltura. Vicenza, 18 February 1769. Giornale d'Italia, 6, p. 156-174.

Arduino, G. 1774. Saggio Fisico-Mineralogico di Lythogonia e Orognosia. Atti dell'Accademia delle Scienze di Siena detta de' Fisiocritici (Siena), 5, p. 228-300.

Arduino, G., 1760. Due lettere [...] sopra varie sue osservazioni naturali: Al Chiaris. Sig. Cavalier Antonio Vallisnieri professore di Storia Naturale nell'Università di Padova: Lettera Prima [...] Sopra varie sue Osservazioni Naturali (Vicenza, 30 gennaio 1759): Lettera Seconda [...] Sopra varie sue Osservazioni fatte in diverse parti del Territorio di Vicenza, ed altrove, appartenenti alla Teoria Terrestre, ed alla Mineralogia (Vicenza, 30 marzo 1759). Nuova Raccolta di Opuscoli Scientifi ci e Filologici (Venezia), 6, p. 99-180. 
Arrigoni, T. 1987. Uno scienziato nella Toscana del Settecento. Giovanni Targioni Tozzetti: Firenze, Gonnelli, 173 p.

Bourdier, F. 1957. Quaternaire. In: Pruvost, P. (Ed.), Lexique stratigraphique international. Vol. 1 Europe. Centre National de la Recherche Scientifique, Paris, pp. 99-100.

Boylan, P. J. 1998. Lyell and the dilemma of Quaternary glaciation. In: Blundell, D. J., Scott, A. C. (eds) Lyell: the past is the key to the present. Geological Society, London, Special Publications, 143, 145-159.

Burnet, T. 1681. Telluris Theoria Sacra: orbis nostri originem et mutationes generales, quas iam subiit aut olim subiturus est, complectens. Libri duo priores de Diluvio and Paradiso. London, G. Kettilby, 306 p.

De Serres, M., 1830. De la simultaneité des terrains de sédiment supérieurs. In: $L a$ Géographie Physique de l'Encyclopedie Methodique, vol. 5, 125 pp.

Desnoyers, J. 1829. Observations sur un ensemble de dépots marins plus récents que les terrains tertiaires du bassin de la Seine, et constituant une formation géologique distincte: précedées d'un apercu de la nonsimultanéité des bassins tertiaires. Annales scientifiques naturelles 16, 171-214, 402-419.

Elias, S.A. 2007. History of Quaternary Science. In Elias, S.A. (ed.) Encyclopedia of Quaternary Science. Volume 1, 10-18. Elsevier: Amsterdam. 852 pp.

Ellenberger, F. 1994. Histoire de la Géologie, Tome 2: La grande éclosion et ses prémices 1660-1810. Paris, Lavoisier, 383 p.

Eyles, V.A. 1969. The extent of geological knowledge in the eighteenth century, and the methods by which it was diffused. In: Schneer, C.J. (ed.) Toward a history of Geology. 159-183. MIT Press: Cambridge Mass.

Gervais, P. 1867-1869. Zoologie et paleontology génerales. In: Nouvelles Recherches sur les Animaux Vertébres et Fossiles, vol 2. Bertrand, Paris, pp. 263.

Gibbard, P.L. \& Kolfschoten, van Th. 2004. Pleistocene and Holocene Series. In: Gradstein, F. Ogg, J. \& Smith A.G. (editors) Geological Time Scale 2004. University Press: Cambridge.

Gliozzi, M. 1962. Arduino, Giovanni. Dizionario Biografico degli Italiani. Volume 4. http://www.treccani.it/enciclopedia/giovanni-arduino_(Dizionario-Biografico)/

Gohau, G. 1990. A history of Geology. Rutgers University Press: London, New Brunswick. $259 \mathrm{pp}$. 
Gortani, M. 1930. Idee precorritrici di Luigi Ferdinando Marsili su la struttura dei monti. In: Comitato Marsiliano, ed., Memorie intorno a Luigi Ferdinando Marsili: Bologna, Zanichelli, pp. 257-275.

Grossi, F. 2015. Giovanni Arduino. The geologist who "invented" the eras. Geoitaliani: https://www.geoitaliani.it/search?q=Arduino.

Head, M.J., Gibbard, P.L., Salvador, A., 2008b. The Tertiary: a proposal for its formal definition. Episodes 31, 248-250.

Knox, R.W.O.'B., Pearson, P.N., Barry, T.L., Condon, D.J., Cope, J.C.W., Gale, A.S., Gibbard, P.L., Kerr, A.C., Hounslow, M.W., Powell, J.H., Rawson, P.F., Smith, A.G., Waters, C.N., Zalasiewicz, J.A., 2012. Examining the case for the use of theTertiary as a formal period or informal unit. Proceedings of the Geologists' Association 123, 390393.

Luzzini, F. 2008. Il Miracolo inutile. Antonio Vallisneri e la scienze della Terra in Europa tra XVII e XVIII secolo. Biblioteca dell'Edizione Nazionale della opere di Antonio Vallisneri. Firenze: Olschki Editore 275pp.

Luzzini F. 2011. Multa curiosa: Vallisneri's early studies on earth sciences. Nuncius. 26, 334354.

Lyell, C. 1830-33. Principles of Geology. volumes 1-3. J. Murray: London.

Lyell, C. 1839. Eléments de Geologie. Pitois-Levrault, Paris.

Lyell, C. 1863. The geological evidences of the antiquity of man: with remarks on theories of the origin of species by variation. J. Murray: London.

Mather, K.F., Mason, S.L. 1970. A source book in Geology 1400-1900. Havard University Press: Cambridge, Mass. 702 pp.

Moro, A.L. 1740, De' crostacei e degli altri marini corpi che si truovano su'monti. Venezia, S. Monti, $452 \mathrm{p}$.

Phillips, J. 1840. Palæozoic series. Penny Cyclopaedia of the Society for the Diffusion of Useful Knowledge. vol. 17. London: Charles Knight and Co. pp. 153-154.

Reboul, H., 1833. Géologie de la période quaternaire et introduction à l'histoire ancienne. Paris: Levrault.

Rudwick, M.J., 2005. Bursting the limits of time: the reconstruction of geohistory in the age of revolution. University of Chicago Press, $708 \mathrm{pp}$.

Sedgwick, A. 1838. A synopsis of the English series of stratified rocks inferior to the Old Red Sandstone - with an attempt to determine the successive natural groups and formations. Proceedings of the Geological Society of London. 2, 675-685. 
Steno, N. 1669. De solido intra solidum naturaliter contento dissertationis prodromus:

Florentiae. Ex Typographia sub signo Stellae, 80 pp.

Targioni Tozzetti, G. 1754. Prodromo della Corografi a e della Topografi a Fisica della Toscana. Firenze, Nella Stamperia Imperiale, 210 pp.

Targioni Tozzetti, G. 1779. Dei Monti ignivomi della Toscana e del Vesuvio, in Dei Volcani o monti ignivomi più noti, e distintamente del Vesuvio. Osservazioni fi siche e notizie istoriche di Uomini Insigni di varj tempi, raccolte con diligenza. Livorno, Calderoni e Faina, p. 7-59.

Vaccari, E. 1992. L'attività agronomica di Pietro e Giovanni Arduino. In: Scienze e tecniche agrarie nel Veneto dell'Ottocento. Venezia, Istituto Veneto di Scienze, Lettere ed Arti, p. $129-167$.

Vaccari, E. 1993. Giovanni Arduino (1714-1795): Il contributo di uno scienziato veneto al dibattito settecentesco sulle scienze della Terra. Firenze: Olschki, 408 pp.

Vaccari, E. 1996. Giovanni Arduino e lo sviluppo della moderna geologia stratigrafica. In: Lazzari C., Bizzarini F. (A cura di), Giovanni Arduino e i geologi veneti del Settecento. Atti del Seminario. Società Veneziana di Scienze Naturali, pp. 37-54.

Vaccari, E. 2006. The "classification" of mountains in eighteenth century Italy and the lithostratigraphic theory of Giovanni Arduino (1714-1795). In: Vai G.B., \& Caldwell W.G.E., The origins of geology in Italy. Geological Society of America Special Paper 411, p. $157-177$

Vallisneri, A. 1715. Lezione Accademica intorno all'origine delle Fontane. Venezia, G.G. Ertz, 87 pp.

Vallisneri, A. 1721. De' corpi marini che su' monti si trovano, della loro origine, e dello stato del mondo avanti il Diluvio, nel Diluvio e dopo il Diluvio. Lettere critiche. Venezia, D. Lovisa, 254 pp.

Walker, M., Head, M.J., Berkelhammer, M., Björck, S, Cheng, H., Cwynar, L. Fisher, D., Gkinis, V., Long., A.J., Lowe, J., Newnham, R., Rasmussen, S.O., Weiss, H. 2018. Formal ratification of the subdivision of the Holocene Series/Epoch (Quaternary System/Period): two new Global Boundary Stratotype Sections and Points (GSSPs) and three new stage/subseries. Episodes, 41, 213-223.

Wendt, H. 1968. Before the deluge. The story of palaeontology. V.Gollancz: London. 419 pp. Woodward, J. 1695. An essay toward a natural history of the Earth and terrestrial bodies especially minerals as also the seas, rivers and springs, with an account of the universal Deluge and of the effects it had upon the Earth. London, R. Wilkin, 277 p. 
Figure and Table captions

Figures

Figure 1. Giovanni Arduino (Library of the Correo Museum, Venice)

Figure 2. Frontispiece of the book De' corpi marini che su' monti si trovano, della loro origine, e dello stato del mondo avanti il Diluvio, nel Diluvio e dopo il Diluvio. Lettere critiche. Published in Venice by Antonio Vallisneri in 1721.

Figure 3. Frontispiece of the Saggio Fisico-mineralogico di Lythogonia e Orognosia (Physico-mineralogical essay of Lythogonia and Orognosia, Arduino (1774).

Figure 4. Cross-section of the Val d'Agno (Agno Valley), $35 \mathrm{~km}$ north of Verona, extending from Recoaro to Montécchio Maggiore, drawn by G. Arduino in 1758. According to Ellenberger (1994) this unique document shows the succession of strata on both sides of the Agno valley. It was drawn on 19-23 October 1758 and represents the exposure $26 \mathrm{~km}$ from the Alps to the Po plain. Its close correspondence with current geological map of the region is striking, being both structurally and stratigraphically accurate, including the substantial faults separating the units labelled A-H, I-L and M-R. In modern terminology the strata shown by Arduino are as follows: A, Palaeozoic crystalline schists; B-G, Permian sediments; H, Limestone and dolomite; I, Middle Triassic Ladinian dolomitic limestone; K, Middle Triassic Ladinian dacitic lavas; L, strongly deformed Norian-Liassic Jurassic sediments; $\mathrm{M}$ Cretaceous clastic limestone; N, P and R, volcanic basalts, tuffs, etc.; O, Lower and Middle Eocene bioclastic sediments and Q, Priabonian (Upper Eocene - Oligocene) calcareous clays. According to Ellenberger (1994, caption his fig. 18), in recognising the strong grouping of units M, N, O, P and Q, Arduino was 60 years ahead of his time (Biblioteca comunale, Verona, "Fondo G. Arduino").

Figure 5. Present-day oblique aerial view of the Val d'Agno, northern Italy looking eastwards (Source: Google Earth 2019). Compare this image with Arduino's sketch along the valley (Fig. 4). Note the contrasting form of the mountain and valley geomorphology. 
Table 1 The lithostratigraphical classification scheme proposed by Arduino in 1759-1760 (modified from Vaccari 2006). (*)The roccia primitivia or monti primitivi (i.e. primitive rocks and mountains) and monte primari (i.e. primary mountains) were previously identified by Tozzetti (1754). See text for explanation. 


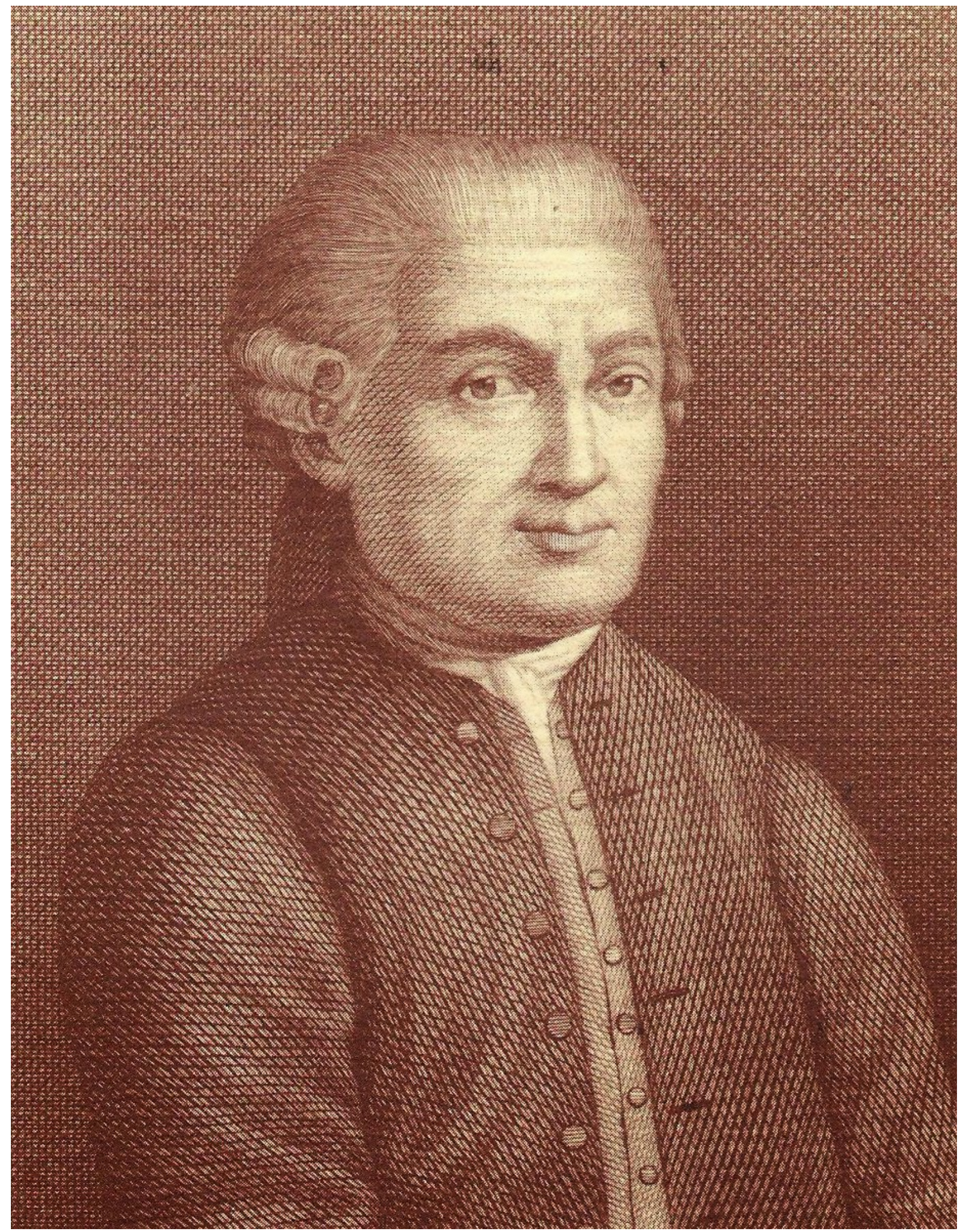




\section{E C O R P I M A R I N I,}

Che fu' Monti fi trovano;

DELLA LORO ORIG IN E; $\mathrm{E}$ dello ftato del Mondo avanti'l Diluvio, nel Diluvio, e dopo il Diluvio:

LETTERE CRITICHE

\section{I A N T O N I O VALLISNERI,}

Pubblico Primario Profeflore di Medicina Teorica nell' Univerfiradi Padora.

Conle Annotazioni,

Alle quali s'aggiungono tre altre Lettere Critiche contra le Opere del Sig.Andry, Francefe, e fuoi Giornali .

A SUA ECCELLENZA LA SIGNORA CONTESSA

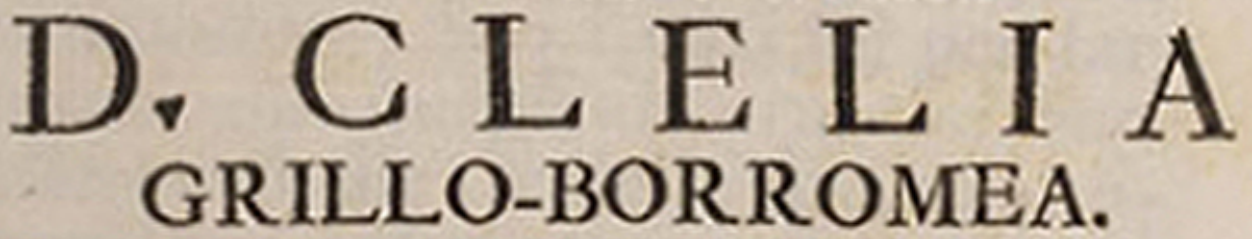

I N VENEZIA, M DCCXXI.

Per Domenico Lovifa.

CON LICENZA DE' SUPERIORI. 
228

\section{$S \quad A \quad G \quad G \quad I \quad O$}

FIS I C O-M I NER ALO G I C O

DILYTHOGONIA,EOROGNOSIA DEL SIGNOR

\section{G I O V A N I A R D U I N O}

PROFESSORE DI MUNERALOGIA, E DI CHIMICA METALLURGICA, PUBBLLCO SOPRINTENDENTE ALLE COSE AGRARIE DELLO STATO VENETO.

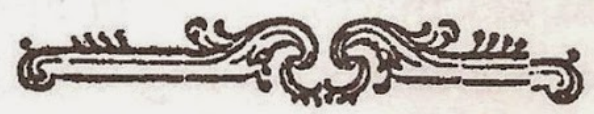

1750 manifeftai le 5) mie congetture intorno alle differen(5) ze di origine, e di natura dei mate* E . riali del Regno Lapideo, cofpicui nel (f) क) ED- 5 - valier Antonio Vallifneri, pubblico Pro. ftolari, dirette al Chiariffimo Sig. Cafeffore d' litoria Naturale nell' Univerfità di Padova, ch' egli fece putblicare (I).

Offervare lungo tempo le fituazioni montuofe, e le pianure di quefti noftri, e di altri paefi, e attentamente contemplate le differenze di modi, e di temoo della loro formazione, manifeftamente apparenti nelle diverfità di fituazione e difpofizione, e di natura, e di fenomeni de' rifpettivi loro materiali, parvemi di pote- 


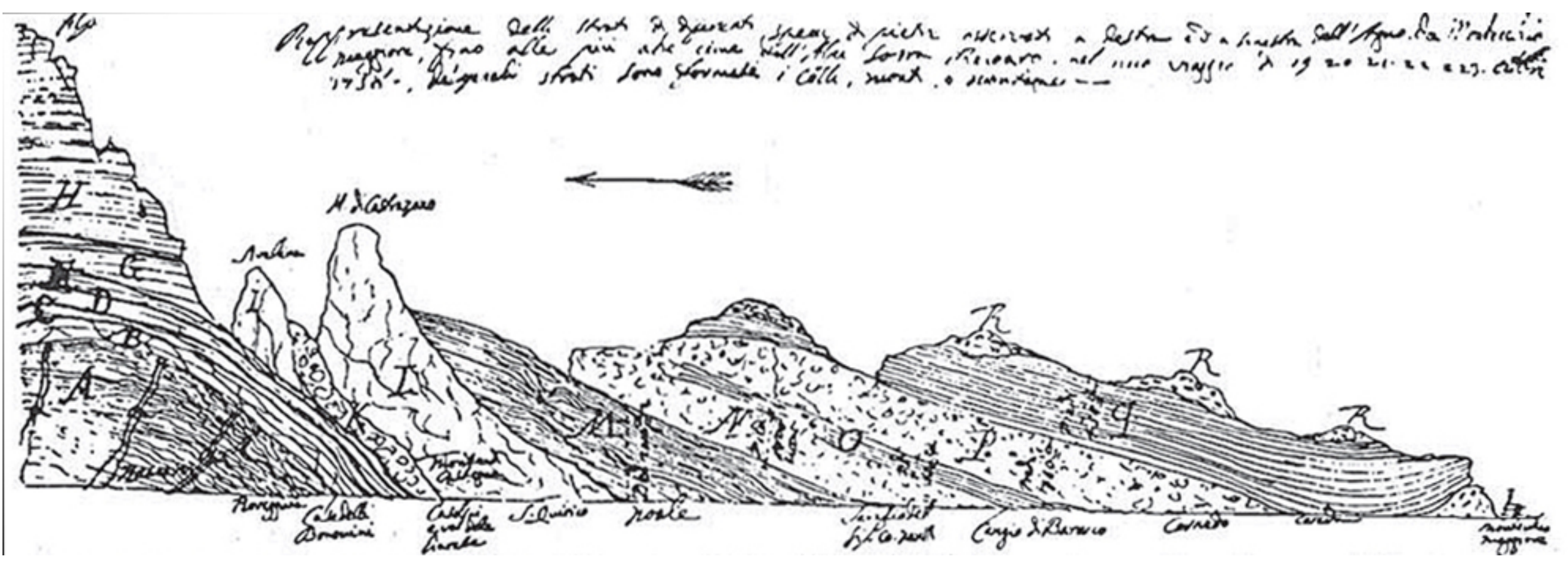




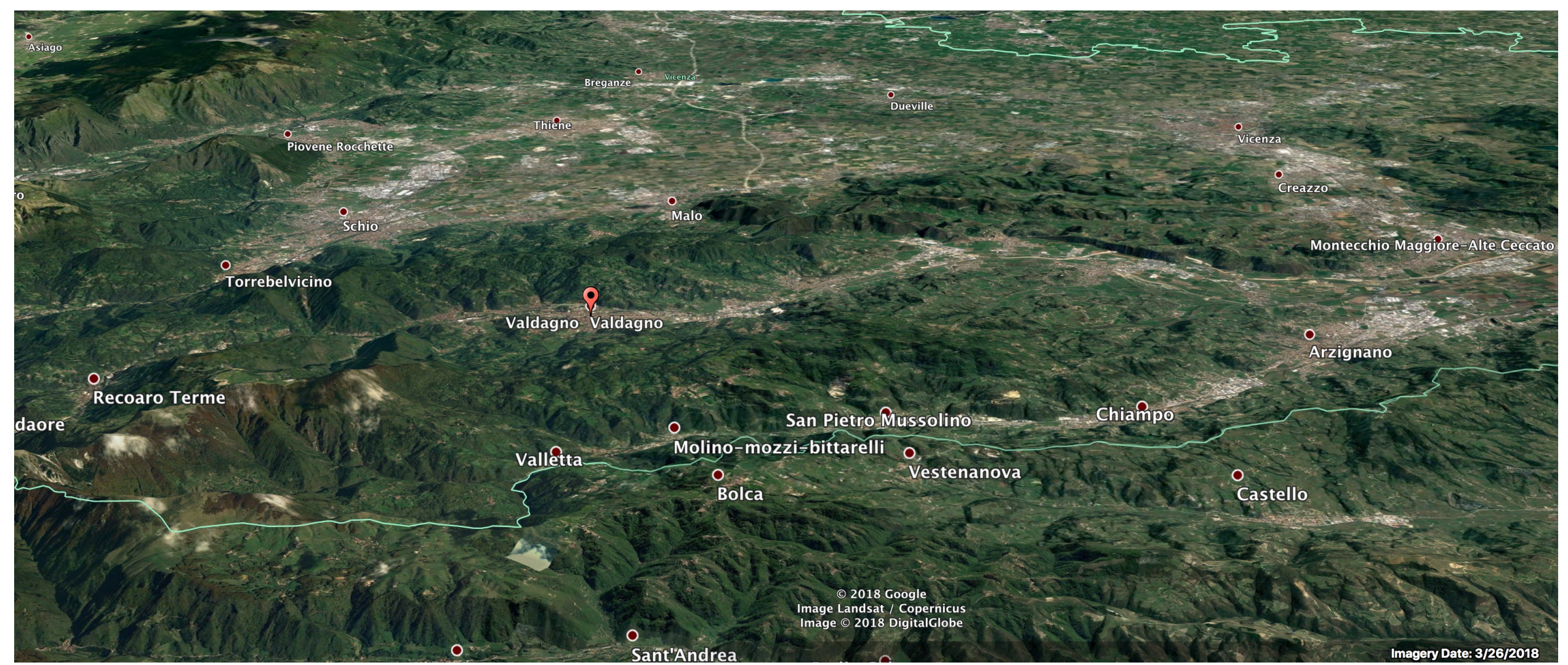




\begin{tabular}{|c|c|c|c|}
\hline Orders (Ordini) & Mountain type & Rock type & Origins \\
\hline $1^{*}$ & $\begin{array}{l}\text { Basement/primaeval (roccia } \\
\text { primitivia) mountains (monti } \\
\text { primitivi) }\end{array}$ & Crystalline schist & $\begin{array}{l}\text { Fire } \\
\text { Cooling of the Earth's surface }\end{array}$ \\
\hline $1^{*}$ & $\begin{array}{l}\text { Primary or mineral mountains } \\
\text { (monti primari o minerali) } \\
\text { a. First subdivision. } \\
\text { b. Second subdivision. }\end{array}$ & $\begin{array}{l}\text { Granite, porphyry and } \\
\text { mineral-bearing crystalline } \\
\text { rocks (rocce vetrescibili), } \\
\text { sandstones and } \\
\text { conglomerates, lacking fossils }\end{array}$ & $\begin{array}{l}\text { Fire, wind and water } \\
\begin{array}{l}\text { a. Volcanism } \\
\text { b. Volcanism and erosion by } \\
\text { wind and water }\end{array}\end{array}$ \\
\hline 2 & $\begin{array}{l}\text { Secondary mountains } \\
\text { (monti secondari) }\end{array}$ & $\begin{array}{l}\text { Marble and stratified } \\
\text { limestones with fossils, } \\
\text { stratified rocks like vetrescibili } \\
\text { but lacking mineral veins }\end{array}$ & $\begin{array}{l}\text { Fire and water } \\
\text { Marine sedimentation and } \\
\text { Modifications by later volcanism }\end{array}$ \\
\hline 3 & $\begin{array}{l}\text { Tertiary mountains } \\
\text { (monti terziari, colline) }\end{array}$ & $\begin{array}{l}\text { Gravel, clay, fossiliferous } \\
\text { sand, volcanic materials }\end{array}$ & $\begin{array}{l}\text { Fire and water } \\
\text { Volcanism and sedimentation in } \\
\text { marine environments }\end{array}$ \\
\hline 4 & $\begin{array}{l}\text { Plains (planure) } \\
\text { (quarto ordine) }\end{array}$ & Alluvial deposits, stratified & $\begin{array}{l}\text { Water } \\
\text { Erosion by rain and rivers }\end{array}$ \\
\hline
\end{tabular}

Table 1 The lithostratigraphical classification scheme proposed by Arduino in 1759-1760. (modified after Vaccari 2006, table 1). (*)The roccia primitivia or monti primitivi (i.e. primitive rocks and mountains) and monte primari (i.e. primary mountains) were previously identified by Tozzetti (1754). See text for explanation. 


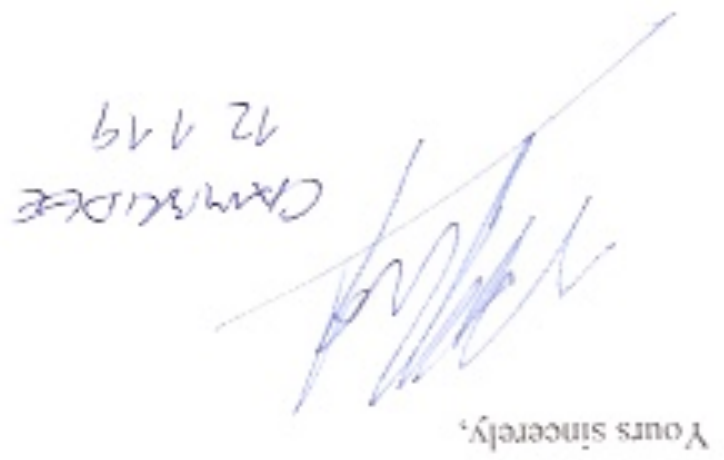

sjoond jo [enoddde [muy pue suoịs!na jo

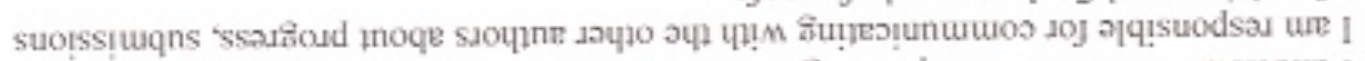

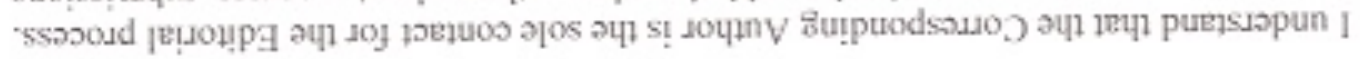

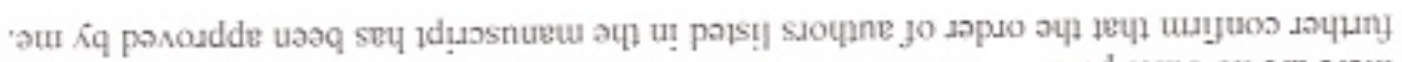

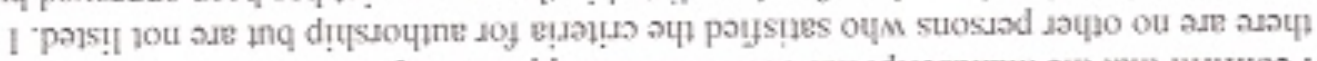

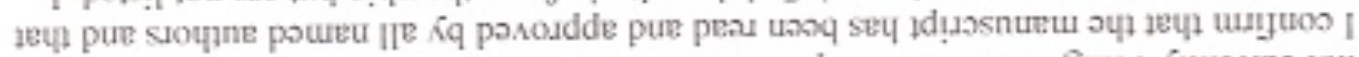

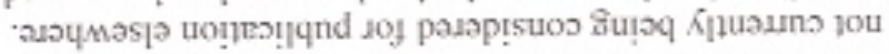

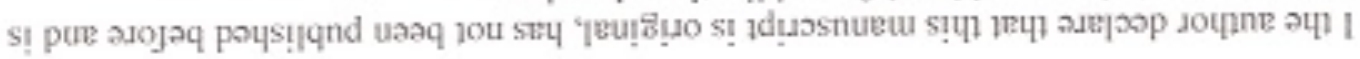

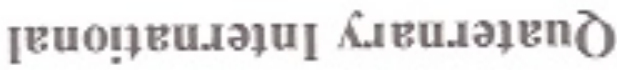

